\title{
熱処理鋼の低速ねじり疲労変形に及に゙す組織の影響*
}

山田嚴** 柿内正昭**

\section{Effect of Micro-Structure on the Fatigue Deformation of Heat Treated Carbon Steel Caused by Slow Cyclic Torsional Stress}

by

\author{
Iwao YAMADA and Masaaki KAKIUCHI \\ (Himeji Technical College)
}

In this report, the fatigue deformation of carbon steel as heat treated and the same followed by plastic twisting or torsional stress-aging were investigated and the effect of micro-structure on the fatigue deformation was studied.

The results obtained are summarized as follows:

(1) Static yield strength is nearly proportional to the fatigue yield strength, therefore, the former may be used as a measure of the latter.

(2) The static yield strength, that is, the fatigue yield strength of the heat treated steel may be affected by the strength of ferrite itself, the magnitude of the mean ferrite path and the magnitude of the resistance against slip of ferrite caused by pre-straining or stress-aging. Hence, the effect of heat treatment, pre-straining and aging on the fatigue deformation may be explained in relation to the three factors mentioned above.

(3) For heat treated steel, the torsional stress-aging is more useful for the prevention of fatigue deformation than cold-working.

(4) In plastically twisted and torsional stress-aged steels the fatigue yield strength is smaller than the yield strength in static tests and the fatigue deformation increases as the mean stress decreases.

(Received Oct. 8, 1960)

\section{1. 緒言}

疲労変形は,これを転位論的にみると, 繰返応力の 作用のもとにおける転位その他の格子欠陷の移動の結 果生ずるものにほかならない.したがって, 疲労降伏 強さと静降伏点または静降伏強さとは一定の関係にあ るのではないかと考えられる，炭素鋼の静降伏点が結 晶粒度や平均フェライトパスによって著しく左右され ることが，転位論的にも実験的にも明らかにされてい るが，これと同様に，炭素鋼の疲労降伏強さも組織の いかんによって著しく変化するであろうと期待される。 以前，筆者らは炭素鋼焼なまし材にねじり応力時効を 施すことによって, 疲労降伏強さが著しく増大するこ とを報告し，これをコットレル効果で説明した。ひず み時効はフェライト中に固溶しているCおよび $\mathrm{N}$ 原子 の数が多いほど起こりやすいから，焼入れ焼もどしな どの熱処理材にねじり応力時効を施すと，焼なまし材 に施す場合より時効が促進されやすく，静降伏強さが

* 原稿受付 昭和 35 年 10 月 8 日, 当協会第 9 期総会講演会にて講 ** 正員 姫路工業大学
上昇する。したがって, 疲労降伏強さも著しく上昇す るであろうと考えられる。本研究はこれらの点を確か めるために行なったものである。

\section{2. 試料および実験方法}

Table 1 のような化学成分の炭素鋼焼なまし材に, Table 2 に示すような熱処理を行なった. 試験片の形 状は Fig. 1 のとおりで, 熱処理後軽くエメリ一紙で 仕上げた。

繰返しねじり試験は静ねじり試験機を用いて手動で 行ない, 繰返速度は約 5 回/分である。なお，ねじり応 力の繰返しに伴う塑性せん断ひずみは次の方法で測定 した。すなわち，あらかじめ数本の試験片について， ねじり試験機付属の相対ねじれ角測定装置の目盛によ って, つかみ部分間の相対ねじれ角 $\theta^{\prime}$ (最小目盛 $1^{\circ}$ )

Table 1 Chemical composition (\%)

\begin{tabular}{c|c|c|c|c|c|c}
\hline Material & C & Si & Mn & P & S & Cu \\
\hline A, D & 0.18 & 0.44 & 0.48 & 0.018 & 0.026 & 0.18 \\
B, C & 0.37 & 0.23 & 0.62 & 0.015 & 0.021 & 0.15 \\
\hline
\end{tabular}


を測定する。それと同時に，別に試験片平行部に取り 付けた 2 個の角度目盛リングから求めたねじれ角 $\theta$ を 用いて, せん断ひずみ (ほぼ直線となる)を作成した。この線図を用いて,つ かみ部分間の相対衫じれ角 $\theta^{\prime}$ から平行部分のせん断 ひずみを求めるようにした。

繰返しねじり試験は応力振幅 $\left(\tau_{a}\right)$ と平均応力 $\left(\tau_{m}\right)$ との比が 0 (常温のクリープ試験に相当する), 1 (片張 り), $\infty$ (両振り)の主として三つの場合について行な い, $\tau_{a} / \tau_{m}=0$ の場合は, 一定の㸚じりモーメントを
負荷している時間の 1 分間が 5 回の繰返数に対応する ものとして取り报った。

ねじり応力時効とは, 所定の温度ふんい気中で所定

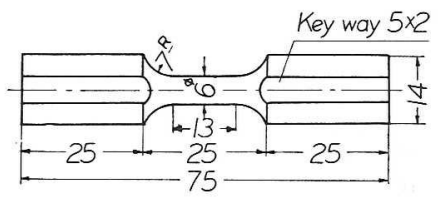

Fig. 1 Detail of specimen

Table 2 Heat treatment

\begin{tabular}{|c|c|c|c|c|c|c|}
\hline \multirow[b]{2}{*}{ Materials } & \multirow[b]{2}{*}{ Heat treatment } & \multicolumn{5}{|c|}{ Mechanical properties } \\
\hline & & $\begin{array}{l}\text { Proportional } \\
\text { limit in } \\
\text { torsion } \\
\qquad \tau_{p} \\
\left.\qquad \mathrm{~kg} / \mathrm{mm}^{2}\right)\end{array}$ & $\begin{array}{c}\text { Yield } \\
\text { strength } \\
\text { in torsion } \\
\tau_{\chi} \\
\left(\mathrm{kg} / \mathrm{mm}^{2}\right)\end{array}$ & $\begin{array}{c}\text { Breaking } \\
\text { shear stress } \\
\text { in torsion } \\
\tau_{B} \\
\left(\mathrm{~kg} / \mathrm{mm}^{2}\right)\end{array}$ & \begin{tabular}{|c|} 
Breaking \\
shear strain \\
in torsion \\
$\gamma_{R}$ \\
$(\mathrm{rad})$
\end{tabular} & $\begin{array}{l}\text { Rockwell } \\
\text { hardness } \\
\qquad B(C)\end{array}$ \\
\hline A & $\begin{array}{l}0.18 \% \text { C-steel was quenched from } 870^{\circ} \mathrm{C} \\
\text { into ice-brine at }-4^{\circ} \mathrm{C} \text { and tempered at } \\
200^{\circ} \mathrm{C}\end{array}$ & $31 \cdot 0$ & $47^{\cdot} 0$ & $87 \cdot 0$ & 0.94 & $102 \cdot 0(28)$ \\
\hline B & $\begin{array}{l}0.37 \% \mathrm{C} \text {-steel was quenched from } 850^{\circ} \mathrm{C} \\
\text { and tempered at } 400^{\circ} \mathrm{C}\end{array}$ & $56 \cdot 0$ & $73 \cdot 0$ & $93 \cdot 0$ & 0.49 & $108 \cdot 0(35)$ \\
\hline $\mathrm{C}$ & $\begin{array}{l}0.37 \% \mathrm{C} \text {-steel was quenched from } 850^{\circ} \mathrm{C} \\
\text { and tempered at } 600^{\circ} \mathrm{C}\end{array}$ & $33 \cdot 0$ & $43^{*} 0$ & $82 \cdot 0$ & $1 \cdot 07$ & $93 \cdot 0$ \\
\hline $\mathrm{D}$ & $0.18 \%$ C-steel was spherodized & $17 \cdot 0$ & $28 \cdot 5$ & $70 \cdot 0$ & $1 \cdot 13$ & $86 \cdot 0$ \\
\hline
\end{tabular}

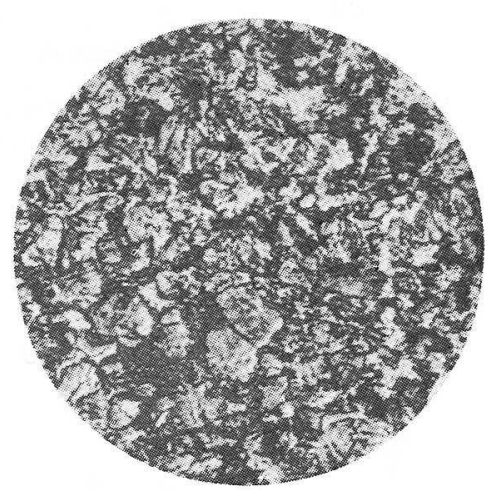

Steel A ( $\times 180)$

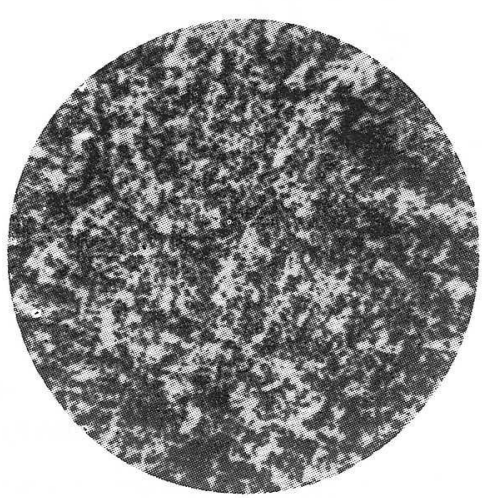

Steel C $(\times 480)$
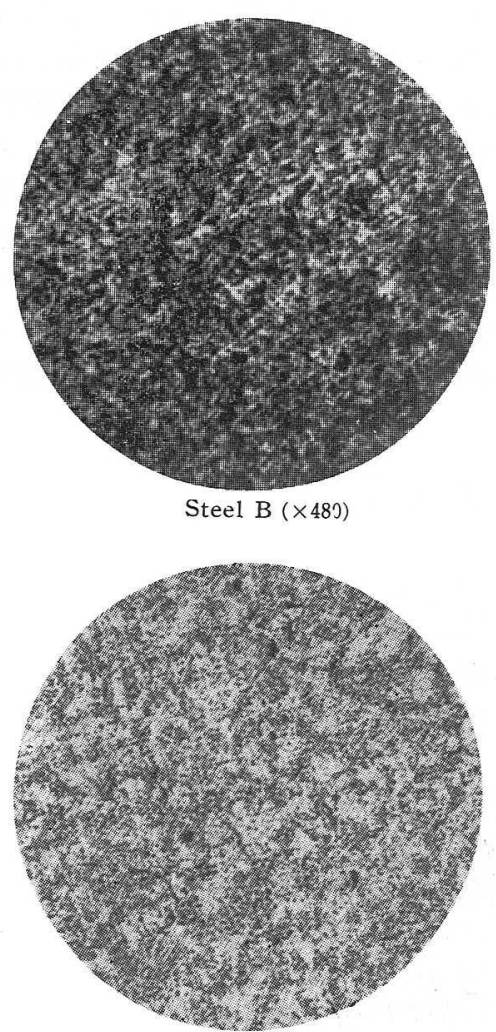

Steel D $(\times 180)$

Photo. 1 Photomicrographs 
時間ねじりモーメントを負荷する処理方法で, 前に行 なった実験結果を参照して $\mathrm{A}$ 材の場合には $200^{\circ} \mathrm{C}, 7$ 分, $\mathrm{C}$ 材の場合には $350^{\circ} \mathrm{C}, 3$ 分の処理を行なった.

\section{3. 実 験 結 果}

\section{（I）熱処理材の場合}

熱処理材 $(\mathrm{A}$ 材, $\mathrm{B}$ 材, $\mathrm{C}$ 材, $\mathrm{D}$ 材)の静ねじり試験 から得られた機械的性質の值は Table 2 に, 顕微鏡 写真は Photo. 1 のとおりである. A 材はフェライト と分散したベーナイトとからなっており，B材はトル 一スタイト， C材はソルバイト， D材は球状セメンタ イト組織からなっている。 B材, C材は同表から明ら かなように $0.37 \% \mathrm{C}$ 鋼を $850^{\circ} \mathrm{C}$ から水焼入れして, $\mathrm{B}$ 材は $400^{\circ} \mathrm{C}, \mathrm{C}$ 材は $600^{\circ} \mathrm{C}$ の焼もどしを行なったも ので，B材の強度に比較してC 材の強度はかなり低い， 焼入鋼の弾性限度は比較的低く, $300^{\circ} \mathrm{C}$ 付近の焼もど しによってかなり上界し, その後 $600^{\circ} \mathrm{C}$ の) 焼もどし温 度までは徐々に低下寸ると言われており，B材，C材 の強度はこの傾向と一致している，ねじりの比例限度 はB 材が最大, $\mathrm{C}$ 材, $\mathrm{A}$ 材, $\mathrm{D}$ 材の順に小さくなって おり, ねじりの降伏強さは $\mathrm{B}, \mathrm{A}, \mathrm{C}, \mathrm{D}$ 材の順になっ ている. B 材の強度は上述の上うに最も高いが, $\gamma_{B}$ の 值が著しく低くじん(鞋)性に欠けていることがわかる.

次に,これら熱処理材について繰返しねじり試験を 行ない, 応力繰返しに伴う疲労変形の变化を測定した. その一例として, C 材の $\tau_{a} / \tau_{m}=1$ の場合を示すと Fig. 2 のとおりである. 繰返応力が $34 \sim 38 \mathrm{~kg} / \mathrm{mm}^{2}$ 程度では疲労变形は全く現われないものと, 繰返しの ごく初期に現われても，その後 1000 回の繰返数以内 に一定となっており, 応力が更に高くなっても繰返数 の增加につれて, 漸次疲労变形の増加がやむ傾向を示 していることがわかる.この傾向は $\tau_{a} / \tau_{m}$ の值のい かんにかかわらず,また，他の組織の場合にもほぼ同 様であった。

次に, 繰返最大せん断応力と塑性せん断ひずみとの 関係を示すと Fig. 3〜6 のとおりである.ただし, 両

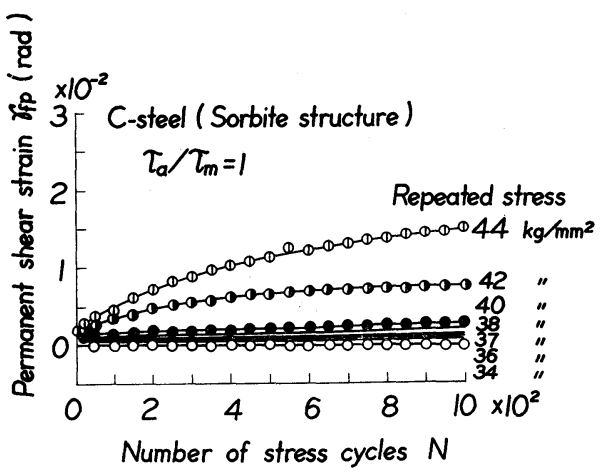

Fig. 2 Variation of fatigue deformation with number of stress cycles
振りの場合には, 疲労変形が+のモーメントの方向に も, 一のモーメントの方向にも起こるから, その大き いほうの疲労变形量の絶対值をとって示してある。こ れらの図から明らかなように, 各熱処理材とも全く同 様の傾向を示し, $\tau_{a} / \tau_{m}$ の值によって, 疲労変形量に かなり大きな相違を示し， $\tau_{a} / \tau_{m}=0$ の場合の曲線は その材料の静ねじり試験の塑性曲線（点線で示したも の)に近くて, 疲労変形が最も少ないが, $\tau_{a} / \tau_{m}=1 お$

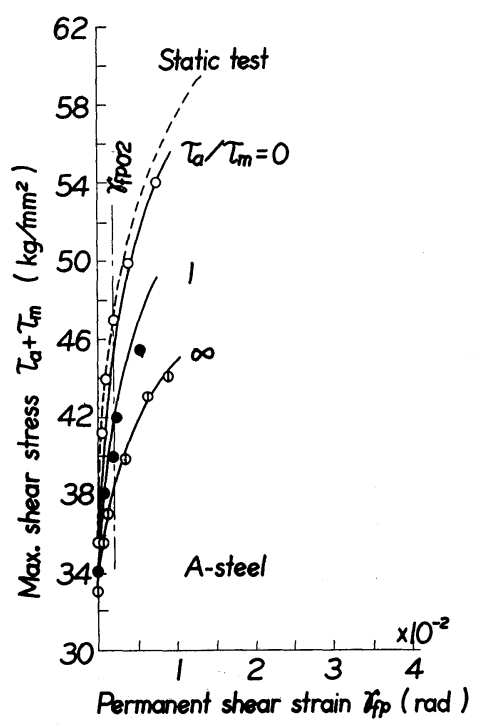

Fig. 3 Relation between maximum shear stress and permanent shear strain in fatigue test

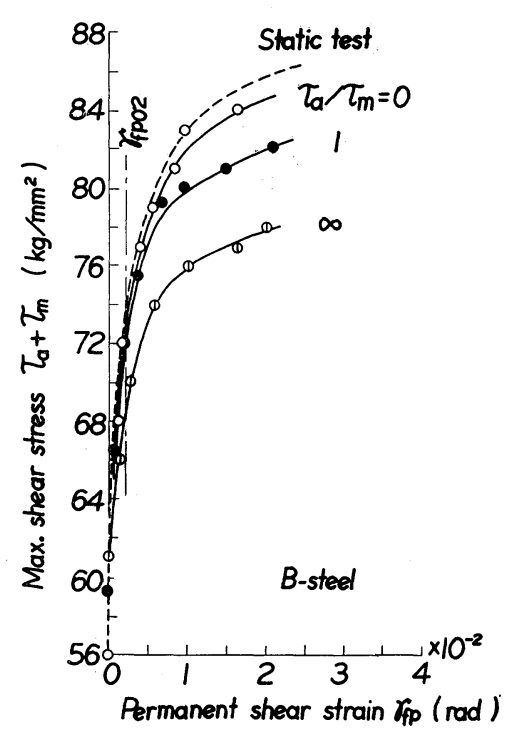

Fig. 4 Relation between maximum shear stress and permanent shear strain in fatigue test 
よびのの順に多くなり， $\tau_{f p_{0} \cdot{ }_{2}}{ }^{*}$ の值が低下する。すな わち, 平均応力が小さくなると疲労変形量が多くなる

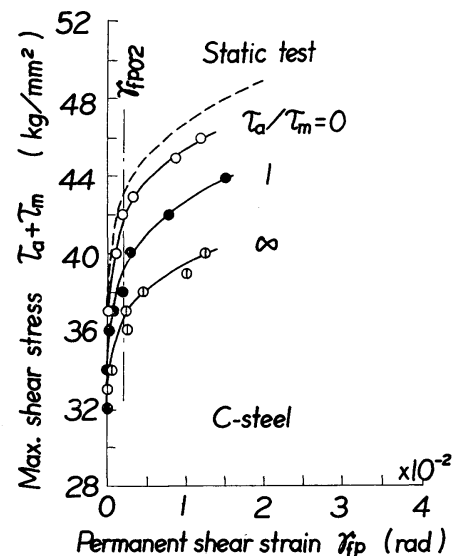

Fig. 5 Relation between maximum shear stress and permanent shear strain in fatigue test

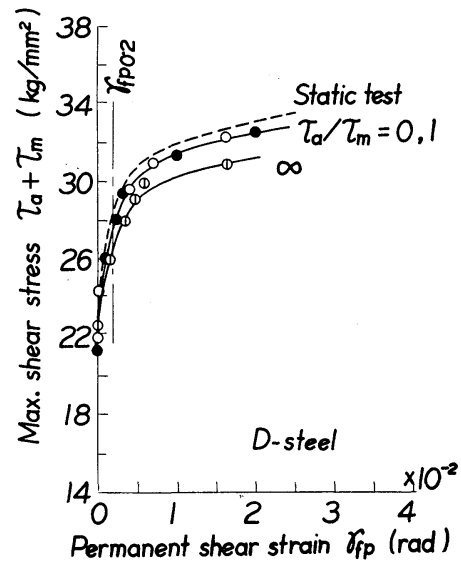

Fig. 6 Relation between maximum shear stress and permanent shear strain in fatigue test
ことがわかる。

（II）熱処理材に加工および応力時効を組み合わせ た場合

Table 2 から明らかなように，前述の熱処理材のう ち，B材はじん性が悪いからこれに更に常温加工や応 力時効を施すと，ますますじん性が低下すると思わ れる.ことに設計值以上の応力が働らくおそれのある ために, 弾性限度の高いことと, じん性の大きいこと を必要とするコイルばねやトージョンバー用材料とし て，B材はあまり良好な材料といいがたい，また $\mathrm{D}$ 材 は降伏強さが低すぎるように思われる。これらの理由 から $\mathrm{B}$ 材， $\mathrm{D}$ 材を除外して， $\mathrm{A}$ 材およびC 材に同一加 工度の常温ねじり加工およびねじり応力時効を施し （加工度はいずれも塑性せん断ひずみ $\gamma_{p}=0 \cdot 147 \mathrm{rad）,}$ 低速ねじり繰返応力による変形の進行状況を調べた.

Table 3 はA材およびC材に常温ねじり加工および ねじり応力時効を施した材料の機械的性質を示したも のである．なお，以後 $\mathrm{A}$ 材およびC材に常温ねじり加 エしたものを $\mathrm{A}_{\mathrm{cw}}$ 材，および $\mathrm{C}_{\mathrm{cw}}$ 材，同じくねじり 応力時効したものをそれぞれ $\mathrm{A}_{\mathrm{sa}}$ 材および $\mathrm{C}_{\mathrm{sa}}$ 材と呼 ぶことにする. Table 2 と Table 3 とを比較して明 らかなように，A材に常温ねじり加工やねじり応力時 効を施すと， $\tau_{y}$ がかなり上昇し，C材の場合にはねじ り応力時効による比例限度の上昇が特に著しく, 比例 限度と降伏強さとが接近し, 弾性域から塑性域へと急 に移行する゙. 熱処理材のままの材料 (A 材, C 材) の $\tau_{p}, \tau_{y}$ およびかたさに対する常温加工材 $\left(\mathrm{A}_{\mathrm{cw}}\right.$ 材, $\mathrm{C}_{\mathrm{cw}}$ 材）および応力時効材 ( $\mathrm{A}_{\mathrm{sa}}$ 材, $\mathrm{C}_{\mathrm{sa}}$ 材) のそれらの变 化率をとると Table 3 の中の括弧内の数字のように なる、これから $\mathrm{A}$ 材に対する応力時効の効果は, C材 のそれに比較して少ないこと，A材およびC材に常温

* 1000 回の綝返数にお汁る疲労変形 $\gamma_{f p}=0.2 \%$ に対応する応力の 意味で, これを疲労降伏強さと呼ぶことにした

**このことはFig. 12 からむ明らかである

Table 3 Mechanical properties of cold worked and stress-aged specimens

\begin{tabular}{|c|c|c|c|c|}
\hline $\begin{array}{ll}\text { Mechanical properties } & \text { Materials } \\
\end{array}$ & Acw & Asa & Cew & $\mathrm{Csa}_{\mathrm{sa}}$ \\
\hline$\underset{\tau_{p}\left(\mathrm{~kg} / \mathrm{mm}^{2}\right)}{\text { Proportional limit in same direction as pre-straining }}$ & $\begin{array}{l}31 \cdot 0 \\
(0 \cdot 0 \%)\end{array}$ & $\begin{array}{l}32 \cdot 0 \\
(3 \cdot 3 \%)\end{array}$ & $\begin{array}{l}33 \cdot 0 \\
(0 \cdot 0 \%)\end{array}$ & $\begin{array}{c}60 \cdot 0 \\
(81 \cdot 7 \%)\end{array}$ \\
\hline$\underset{\tau_{p^{\prime}}}{\text { Proportional }\left(\mathrm{kg} / \mathrm{mm}^{2}\right)}$ limit in opposite direction to pre-straining & $4 \cdot 0$ & $8 \cdot 0$ & $5 \cdot 0$ & $34 \cdot 0$ \\
\hline $\begin{array}{l}\text { Yield strength in same direction as pre-straining } \\
\tau_{y}\left(\mathrm{~kg} / \mathrm{mm}^{2}\right)\end{array}$ & $\begin{array}{c}58 \cdot 0 \\
(23 \cdot 4 \%)\end{array}$ & $\begin{array}{c}66 \cdot 0 \\
(40 \cdot 4 \%)\end{array}$ & $\begin{array}{c}56 \cdot 5 \\
(31 \cdot 4 \%)\end{array}$ & $\begin{array}{c}68 \cdot 0 \\
(58 \cdot 1 \%)\end{array}$ \\
\hline $\begin{array}{l}\text { Yield strength in opposite direction to pre-straining } \\
\tau_{y}\left(\mathrm{~kg} / \mathrm{mm}^{2}\right)\end{array}$ & $28 \cdot 0$ & $30 \cdot 0$ & $19 \cdot 5$ & $44 \cdot 0$ \\
\hline $\begin{array}{l}\text { Breaking shear strain in same direction as pre-straining } \\
\gamma_{B}(\mathrm{rad})\end{array}$ & $\begin{array}{c}0.51 \\
(-45 \cdot 7 \%)\end{array}$ & $\begin{array}{c}0 \cdot 44 \\
(-53 \cdot 2 \%)\end{array}$ & $\begin{array}{c}0.90 \\
(-15 \cdot 9 \%)\end{array}$ & $\begin{array}{c}0 \cdot 75 \\
(-29 \cdot 9 \%) \\
\end{array}$ \\
\hline $\begin{array}{l}\text { Breaking shear strain in opposite direction to pre-strain- } \\
\text { ing } \gamma_{B^{\prime}}(\mathrm{rad})\end{array}$ & $0 \cdot 82$ & $0 \cdot 76$ & $1 \cdot 15$ & 0.95 \\
\hline Hardness (Rockwell $B$ ) $H_{B}$ & $\begin{array}{l}104 \\
(2 \cdot 0 \%)\end{array}$ & $\begin{array}{l}105 \\
(2 \cdot 9 \%)\end{array}$ & $\begin{array}{c}95 \\
(2 \cdot 1 \%)\end{array}$ & $(0.0 \%)$ \\
\hline
\end{tabular}


加工や応力時効を施しても硬度の増加率が少なく，こ とに $\mathrm{C}_{\mathrm{cw}}$ 材や $\mathrm{C}_{\mathrm{sa}}$ 材ではほとんど硬度の増加が見られ ないか, むしろやや軟化を示す場合もあった。

次に, $\mathrm{A}_{\mathrm{cw}}, \mathrm{A}_{\mathrm{sa}}, \mathrm{C}_{\mathrm{cw}}, \mathrm{C}_{\mathrm{sa}}$ 材に低速ねじり繰返応 力を加えた場合の疲労变形を調べた，Fig. 7 と Fig. 8 はそれぞれ $\mathrm{A}_{\mathrm{cw}}, \mathrm{A}_{\mathrm{sa}}$ 材に片振り $\left(\tau_{a} / \tau_{m}=1\right)$ のね じり繰返応力を加えた場合の例であるが，他の材料お よび繰返応力条件の場合でも全く同様の傾向を示した. 常温加工材では, 疲労变形は主として繰返しの初期に 起こるが, 繰返数が増加するにつれて変形の増加がし だいにやみ, 特に繰返応力が低い範囲では, 全く变形 が現われないか, 現われても 1000 回以内に一定とな り, 疲学变形がそれ以上進行しなくなっている. 応力 時効材の場合にも, 繰返応力の低い範囲では常温加工 材の場合とほぼ同様の傾向を示しているが, 繰返応力 がある程度以上になると, 疲労变形が繰返数に伴って ますます増加する傾向を示す.

Fig. 9〜12 はいずれも疲労变形と最大せん断応力と の関係を求めたものである.Fig. 9 は $\mathrm{A}_{\mathrm{cw}}$ 材の場合 で, $\tau_{a} / \tau_{m}=3$ の場合には応力が低い範囲では前加工 と逆方向に变形が現われるが, ある程度以上の応力に なると，前加工と同方向に進行する。この傾向も焼な

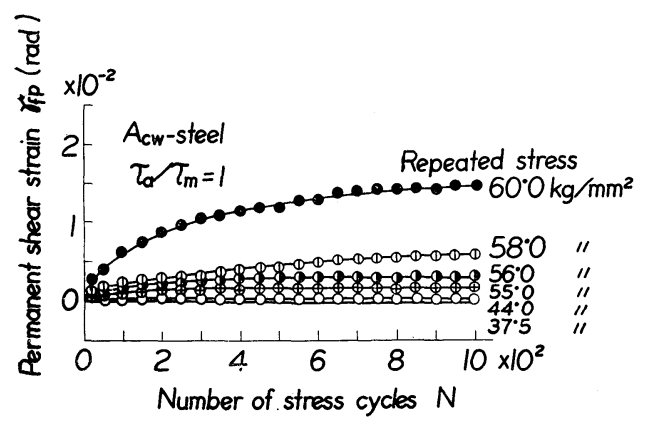

Fig. 7 Variation of fatigue deformation with number of stress cycles

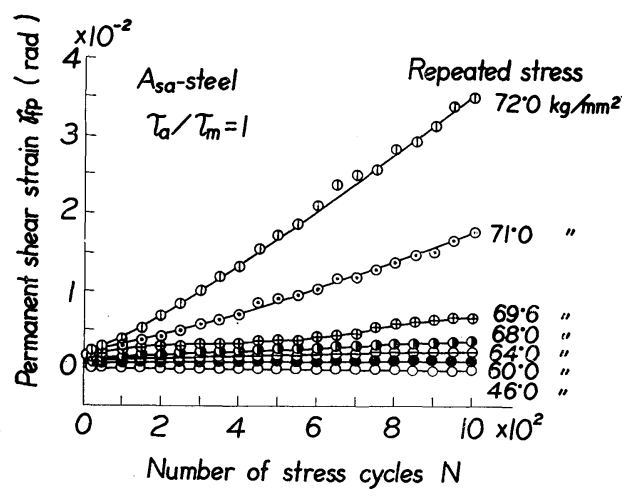

Fig. 8 Variation of fatigue deformation with number of stress cycles
まし材に常温ねじり加工を施した場合と同様であっで， バウシンガー効果が応力繰返し中に変化することによ るものと考えられる. Fig. 10 は $\mathrm{A}_{\mathrm{sa}}$ 材, Fig. 11 は $\mathrm{C}_{\mathrm{cw}}$ 材, Fig. 12 は $\mathrm{C}_{\mathrm{sa}}$ 材の場合であるが, いずれの場合

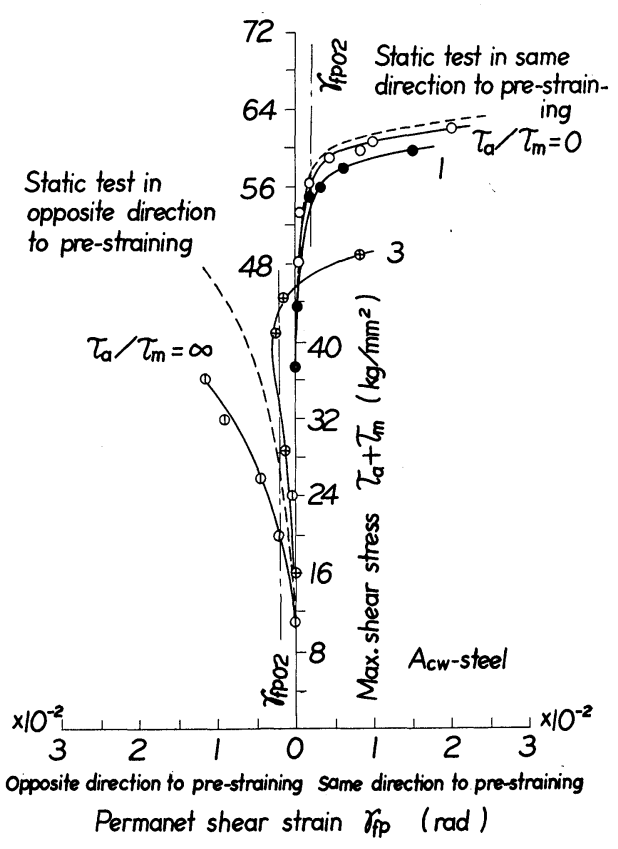

Fig. 9 Relation between maximum shear stress and permanent shear strain in fatigue test

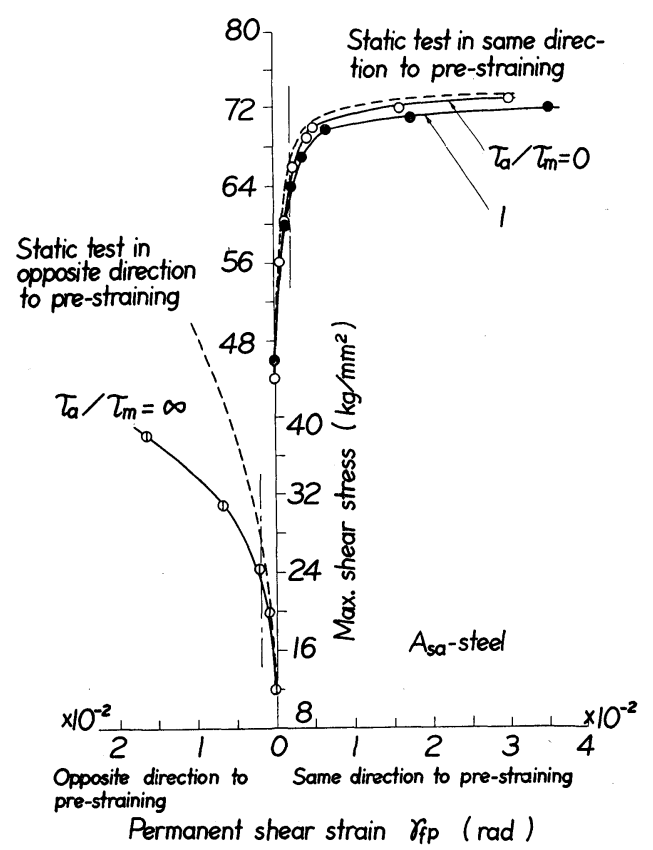

Fig. 10 Relation between maximum shear stress and permanent shear strain in fatigue test 
にも $\tau_{a} / \tau_{m}=0,1, \infty$ の順に低い応力で疲労変形が発 生しやすく, 平均応力が小さくなるほど疲労变形量が 大きくなることがわかる．

\section{4. 結果に対する考察}

（I）静降伏強さと疲労降伏強さとの関係について 上述の実験結果に基づいて， $\tau_{a} / \tau_{m}$ の各值に対する 疲労降伏強さ $\tau_{f p_{0} \cdot 2}$ の值を求め, 静的降伏強さと疲労 降伏強さとの関係を求めると Fig. 13 のようになる.

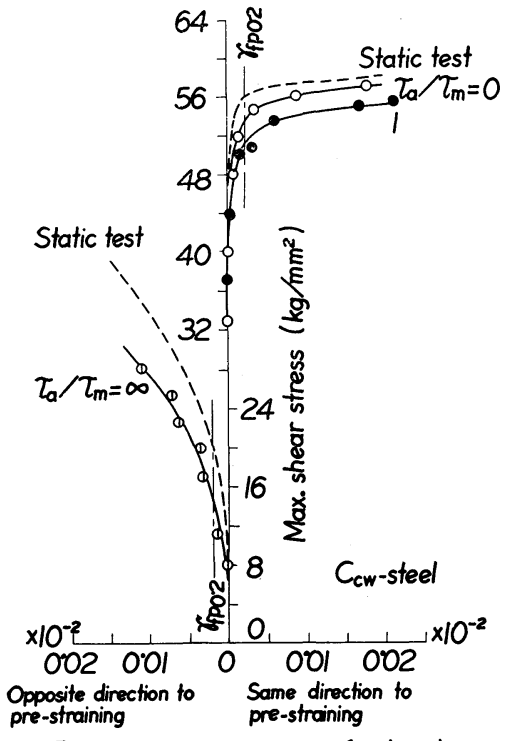

Permanent shear strain $\gamma_{f p}$ (rad)

Fig. 11 Relation between maximum shear stress and permanent shear strain in fatigue test

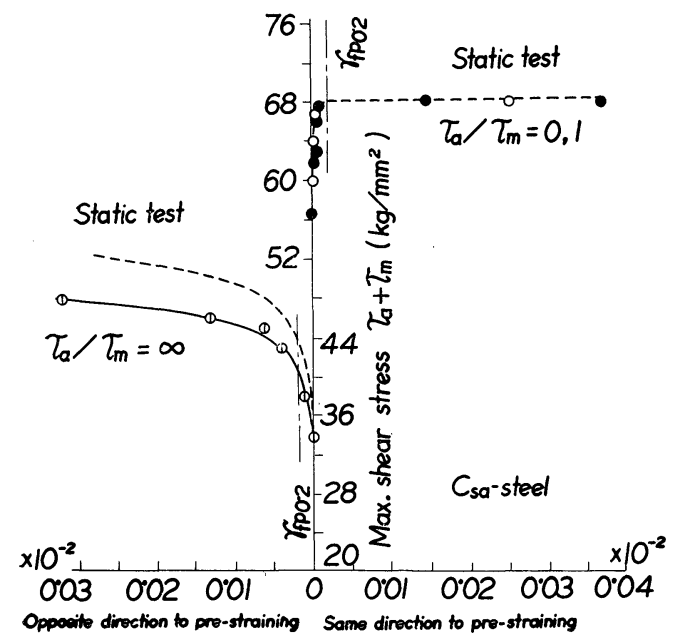

Permanent shear strain $\delta_{\text {fp }}$ (rad)

Fig. 12 Relation between maximum shear stress and permanent shear strain in fatigue test
Fig. 13 は疲労変形量が $0.2 \%$ に対応する疲労降伏 強さの場合である。ただし，常温加工材あるいは応力 時効材で $\tau_{a} / \tau_{m}=\infty$ の場合には，主として前加工と 逆方向にかかる最小応力によって疲労变形が進行する から, 静降伏強さとしては前加工と逆方向の静降伏強 さをとって，同図の矢印のように修正して表わした．

$\tau_{a} / \tau_{m}$ の值によって多少傾斜は異なるが，疲労降伏 強さ $\tau_{f p}$ と静降伏強さ $\tau_{y}$ (前加工と同方向における) あるいは $\tau_{y^{\prime}}$ (前加工と逆方向における) との間には， ほぼ比例関係が成立することがわかる。したがって， 熱処理材のうち，静降伏強さの高い材料ほど疲労降伏 強さが高く, 静降伏強さを疲労変形抵抗の大小を表わ す一つの尺度として利用しうるように思われる。

単一方向の応力 (unidirectional stress), すなわち, 静的応力を受けた場合に現われるすべり帯と, 繰返応 力を受けた場合に現われるすべり帯との間には，その 分布, 形状に関してかなり明りょうな相違点が存在す ることが既に明らかにされている。すなわち，前者の すべり帯は各結晶粒についてかなり一様に分布してい るが，後者の場合には，すべり帯が局部的に集中して おり，繰返数が多くなると，すべり帯の幅が広くなる ことが認められている.作用応力の種類や繰返速度に よるこのようなすべり帯の相違の原因はまだ明らかに されていないが, 繰返応力による变形も, 静的応力に よる変形も，ともに基本的にはそれぞれの応力のもと における転位その他の格子欠陷の挙動に関連して生じ たものであることに変わりはないはずである．したが って, 静降伏強さと疲労降伏強さとがほぼ比例関係に あることは，ある程度当然のようにも思われる。

鉄鋼の静降伏点は温度や応力速度などが一定であれ ば，転位がすべり面上を移動するときの抵抗力の大小， 結晶粒度あるいは平均フェライトパスの大小, ならび

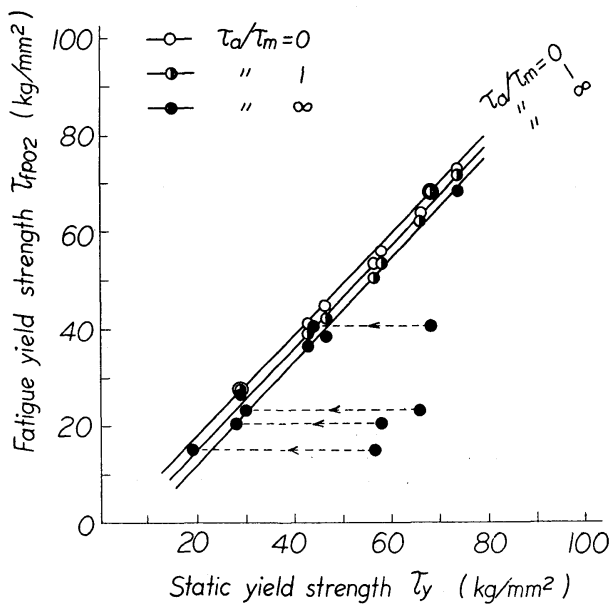

Fig. 13 Relation between static yield strength and fatigue yield strength 
に堅いせメンタイトやパーライトの形状，分布に関連 する応力集中の程度などの影響を受ける。降伏点のみ ならず，降伏強さについても同様の関係が成立するも のと仮定してみる. セメンタイトが球状化した B , C, $\mathrm{D}$ 材では，この順序にセメンタイト球の大きさおよび 平均フェライトパスの大きざが大くなっており，フ ェライト部分のすべり抵抗も $\mathrm{B}, \mathrm{C}, \mathrm{D}$ 材の順に小さい と考えられるから, 静降伏強さは $\mathrm{D}, \mathrm{C}, \mathrm{B}$ 材の順に大 さいはずである，静降伏強さに関する実験結果は上の 定性的な考察と一致しており，上述の仮定がほぼ成立 するものと考えられる。これらの熱処理材に更に常温 ねじり加工やねじり応力時効を施せば，更にすべり抵 抗が増大して（コットレル効果による転位の固着作用 も含めて), 当然静降伏強さならびに波労降伏強さを 増大する゙。なお，A材ならびにC材に施したねじり応 力時効の処理条件(特に時効時間)は焼なまし材の場合 を参照して選定したが，時効はフェライト中に固溶し ているNおよびC原子の数が多いほど起こりやすいか ら, 焼入れ焼もどし材などの最適時効時間は, 焼なま し材の場合よりやや短時間側にずれると考えられる. したがって, 各熱処理材について最適の時効時間を求 めて応力時効を行なえば, 疲労変形の防止効果は更に 上がるものと考えられる。

次に，A材は低炭素マルテンサイト組織を目標とし て焼入れ処理を行ない，これを更に $200^{\circ} \mathrm{C} て ゙$ 焼もどし したものであるが, 焼入れのままのものと, 焼入れ後 $200^{\circ} \mathrm{C}$ で尭もどしたものとの組織はほとんど变わって いなかったし, 焼入れのままの硬度は 230 DPN で低 炭素マルテンサイト組織の硬度 $350 \mathrm{DPN}$ 程度と比較 して，かなり低かった．これは試料の直径は $6 \mathrm{~mm}$ あるが, 太いつかみ部分が影響して, 冷却速度がおそ くなり, Photo. 1 (a) に示すようなベーナイトの分 散した組織となったものと思われる。Aborn は低炭 素マルテンサイト材を $200^{\circ} \mathrm{C}$ 前後で焼もどして，かな り高い $125 \mathrm{~kg} / \mathrm{mm}^{2}$ の引張降伏強さを得ているから筆 者らの場合にも焼入れ冷却速度をごく早くするか，あ るいは激しい急熱，急冷を行なうことによって低炭素 マルテンサイトとした後, $200^{\circ} \mathrm{C}$ 前後で焼もどせば, 更に疲労降伏強さの高いC材にまさる材料が得られた のではないかと推察され，そのじん性の良好さととも に有望な材料と筆者は考えているが，これについては 別に検討したい.

\section{(II) 疲労変形限度線図}

上述の実験結果に基づいて, 疲労降伏強さを耐久限 度線図上にプロットすると Fig. 14 のようになる。た だし，同図には前に報告した $0.37 \% \mathrm{C}$ 鋼の焼なまし 材に常温ねじり加工およびねじり応力時効を施した場 合も点線で示してある.
焼なまし材，熱処理材ともにほぼ值線で示されるの に反し，これらの材料に常温加工や応力時効を加える と, 片振りの領域では疲労変形抵抗の上升が見られる が, 両振りの領域では, むしろ变形抵抗が低下する. 両振りの領域での疲労降伏強さの低下は前加工による バウシンガー効果のためであると考えられる. したが って，片振りおよび両振りの全域について疲労变形抵 抗を大きくするためには，熱処理のみによって降伏強 さを高めることが望ましいが, 強度の増大はじん性の 低下と結びっく場合が多い。したがって, 静的強度は やや低いがじん性に富んでいる材料，たとえばC材に 応力時効を施すのがよい，ただし，この場合には両振 りの領域で疲労降伏強さが低下することはやむをえな い.

疲労变形防止上有効な処理方法を選択するにあたっ て, その部品に働く応力が片振りの範囲にとどまるも のか，両振りの筫囲に及ぶものであるか，また，かな りのじん性を必要とするものであるかを考え, これら の諸点の兼ね合いから熱処理のみによって疲労変形の 防止を図るか，熱処理に常温加工あるいは応力時効を 適用して, 疲労变形の防止を図るかを選定しなければ ならない。

\section{5. 結論}

炭素鋼熱処理材ならびに熱処理材に更に常温ねじり 加工あるいはねじり応力時効を行なった材料について 平均応力を種々変えて, どのようにねじり疲労変形が 進行するかを調ヘ，ねじり疲労变形に及ぼす組織の影 響について考察した。，その結果を要約すると次のよう である。

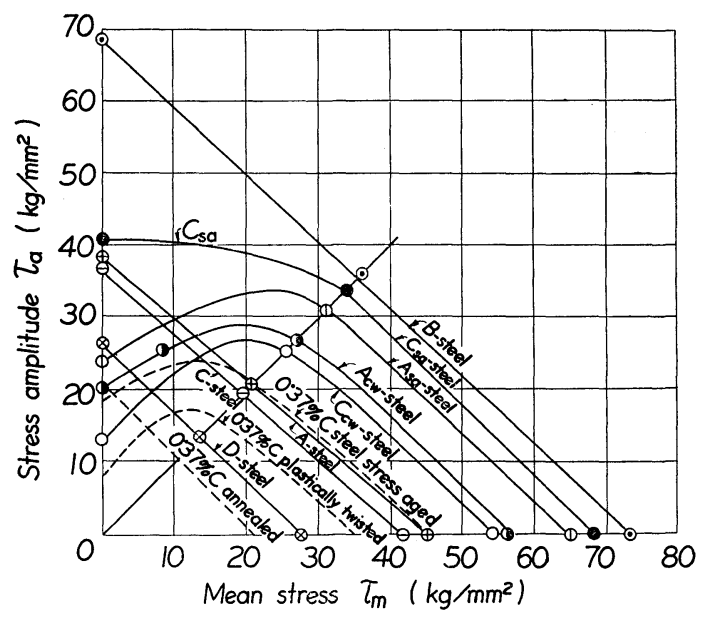

Fig. 14 Diagram of fatigue deformation sa: stress aged, cw : plastically twisted

* 実測しなかったが一般的にこのように考えてさしつかえなからう ***だし, 両振りの領域を除く 
（1）炭素鋼熱処理材ならびに熱処理材に更に常温 ねじり加工あるいはねじり応力時効を施した材料のい ずれの場合にも静降伏強さと疲労降伏強さとはほぼ比 例関係にあり, 静降伏点あるいは降伏強さの増強改善 策がそのまま疲労降伏強さの増強策に通ずることがわ かった

（2）したがって，炭素鋼の疲労降伏強さの大小を 判定する尺度として, 静降伏点あるいは降伏強さを使 用しうるように思われる。

（3）熱処理材の静降伏強さ,ひいては疲労降伏強 さはフェライトの固溶炭素量に関係するフェライト自 身の強度と加工, 時効などによるフェライトのすべり 抵抗と, セメンタイトの大きさ，分布状態，すなわち， 平均フェライトパスなどに関係する。したがって, 疲 労变形に対する熱処理, 加工, 時効等の効果も上述の 諸量との関連において説明することができる.

（4）焼なまし材の場合と同様, 熱処理材に対して も, 応力時効処理は疲労变形の防止に有効である.

（5）熱処理材の疲学降伏強さは, その材料の静降 伏強さより低く, かつ, 平均応力が小さくなるほど疲 労変形量がやや大きくなる傾向がある.

（6）熱処理材に常温ねじり加工あるいはねじり応 力時効を施すと $(4)$ の傾向が特に著しくなり, 片振り の領域 $\left(0 \leqq \tau_{a} / \tau_{m} \leqq 1\right)$ では熱処理のままのものより疲 労变形抵抗が増大するが, 両振りの領域 $\left(1 \leqq \tau_{a} / \tau_{m} \leqq\right.$ ○)ではかえって減少する。これは前加工によるバウ
シンガー効果のためである。したがって使用応力が片 振りの領域にあるか，雨振りの領域に及ぶものである かによって熱処理のみ施すほうが有利であるか, 熱処 理材に更に応力時効を施すほうが有利であるかを選定 しなければならない。

終りにのぞみ, 種々御指導御批判を賜わりました大 阪大学工学部教授篠田軍治先生ならびに本学教授桜井 忠一先生，および，鋼材を提供していただいた川崎製 鉄技術研究所長今井光雄博士に厚く御礼申し上げると ともに, 当時本学の学生として熱心に実際に協力され た荒木正（大阪金属工業株式会社）ならびに藤井敏和 (松下電器産業株式会社)両氏に感謝する.

\section{参考 文 献}

1) M. Gensamer, E.B. Pearsall, W.S. Pellini and J.R. Low, Tïans. ASM, 30, 983 (1942)

2) C.S. Roberts, R.C. Carruthers and B.L. Averbach, Trans. ASM. 44, 1150 (1952)

3) A.N. Turkalo and J.R. Low, Trans. AIME, 212, 750 (1958)

4) 山田, 吉田, 姫路工業大学研究報告, No. 12, 7 (1960)

5) 桜井, 山田, 柿内, 材料試験, 7, 62, 618 (1958)

6）たと兄ば H. Muir, B.L. Averbach, M. Cohen, Trans ASM, 47, 380 (1955)

7）日本バネ協会編，ばね，9（1959）丸善

8) 山田, 材料試験, 8, 74, 830 (1959)

9) たと党ば, F.P. Bullen, A.K. Head and W.A. Wood : Proc. Roy. Soc. London A 216, 332 (1953)

10) A.H. Cottrel, Chartered Mech. Eng., 4, 448 (1957)

11）横堀, 機械の研究, 11, 980, 1237 (1959)

12）山中, 金属, 30, No. 2, 12 (1960)

13) R.H. Aborn, Trans. ASM, 48, 51 (1956)

\section{アルミニウム合金の一定ならびに変動振幅荷重疲労} 試験 (Axial-Load Fatigue Tests of 2024-T3 and 7074-T6 Aluminum-Alloy Sheet Specimens under Constant- and Variable-Amplitude Loads) E.C. Naumann, H.F. Hardrath and D.E. Guthrie, NASA, Tech. Note, D-212 (1959)

2024-T3 および 7075-T6 の 2 種のアルミニウム合 金板状試験片 $\left(\alpha_{k}=4\right)$ につて荷重振幅一定ならびに 変動荷重振幅の繰返引張生縮疲労試験を行なった。試 験機は偏心回転質量によって励振し荷重振幅を生ぜし め, 平均応力はばねでかけられ, いずれもレバーで拡 大されて試験片に両振または片振の軸方向繰返荷重を 作用せしめるものである. 繰返速度は $1800 \mathrm{cpm}$, 準 共振型である．荷重をプログラムとおりに制御するた めに油圧駆動の制御装置を用いている. 疲労試験とし て一定応力振幅, 多段多重重複繰返応力 (応力上昇, 下 降，上昇 $\rightarrow$ 下降，および下降 $\rightarrow$ 上年の 4 種）ならびに 突風ひん(頻)度に近似した不規則繰返応力の計 6 種の 試験を行ない種々の試験条件の影響について調べた。
試験の結果はすべて累積繰返数比 $\sum \frac{n}{N}$ の值で整理し, ある一つの試験条件のみが異なる 2 種のグループにつ いては $t$ 分布により検定を行なって統計的にその結果 を論じた. 結論として, (1)応力作用順序の寿命に及 ぼす影響は著しく， $\sum \frac{n}{N}$ の值は多段多重重複で応力 下降の場合に最も大きく, 応力上昇 $\rightarrow$ 下降, 下降 $\rightarrow$ 上 并, 不規則応力の順に小さくなり, 多段多重重複, 応力 上昇の場合に最も小さい．この原因は圧縮残留応力に よるものだと説明した。（2）平均応力が高いほど $\sum \frac{n}{N}$ の值は大きい. これも残留応力によるものと解 釈した。（3）7075-T6 は 2024-T3 より $\sum \frac{n}{N}$ の值 が大きい。（4）変動 1 周期中に含まれる繰返数が少 ないほど $\Sigma \frac{n}{N}$ の值は大きい.（5）応力段数および 応力スペクトルの型の影響については結論を下すには 資料不足である.（6） $\Sigma \frac{n}{N}$ 算定の基礎となる $S-N$ 曲線の信頼性や破壊時の応力レベルについても述べて いる.（訳者注一結論の（1）は必ずしも一般の傾向を 表わしていない. ゆえに残留応力のみによる説明は適 当でないと思われる.)

（中川隆夫） 